\title{
Stress-strain state of a borehole determined analytically using drilling-out as a technology of reducing differential settlement
}

\author{
${ }^{1}$ Yakov A. Pronozin, ${ }^{1}$ Mikhail D. Kajgorodov, ${ }^{2}$ Aleksandr D. Gerber \\ ${ }^{1}$ Industrial University of Tyumen, Tyumen, Russia \\ ${ }^{2} \ll$ Marshal of Engineering Troops A.I. Proshlyakov Higher Military Engineering \\ Command School of Tyumen» Ministry of Defense of the Russian Federation, Tyumen, Russia
}

Corresponding author: Mikhail D. Kajgorodov, e-mail: heklerkox@gmail.com

\begin{abstract}
The existing approaches for reducing the differential settlements of buildings and structures have their own advantages and disadvantages. Lowering of a building or part of it is one of the promising methods to reduce the differential settlements of shallow foundations resting upon weak silt-loam soils. The effect is achieved by drilling-out vertical boreholes in the immediate vicinity of the foundation from the minimal settlements. Method: Russian and foreign scientists have been involved in the development of calculation procedures for horizontal and inclined drilling-out of boreholes. It has been important to determine drilling parameters when using this technology and how soil characteristics and stress state of soils around the borehole influence the reduction of differential settlements. The paper discusses the influence of the strength characteristics of soils on the stress state of the soil massif around the borehole, as well as the influence of the borehole radius on the formed areas of limit state. The analytical solution is
\end{abstract}

based on the well-known ratio used to determine the stress state around the borehole during pressure tests. Tangential and radial stresses are determined from this ratio; next, they are checked according to the condition of the strength law, and thus, the stress state around the borehole becomes evident. Result: The stress state of the soil around the boreholes has been calculated by the given method; it has made it possible to calculate the areas of soil destruction and determine the parameters of boreholes and their geometry depending on the purposes when regulating the settlements of slab foundations. It has been established that drilling behind the foundation contour in relation to drilling in the foundation contour makes it possible to increase the radius of the plastic deformation zone up to two times under the same soil conditions and well geometry.

Keywords: differential settlement; tilt; drilling-out; shallow foundations; drilling parameters; cuff technology; tangential stresses; radial stresses 


\title{
Аналитическое определение напряженного состояния скважины при использовании технологии снижения неравномерности осадок методом выбуривания
}

\author{
${ }^{1}$ Пронозин Я.А., ${ }^{1}$ Кайгородов М.Д., ${ }^{2}$ Гербер А.Д. \\ ${ }^{1}$ ФГБОУ ВО «Тюменский индустриальный университет», Тюмень, Россия \\ ${ }^{2}$ ФГКВОУ ВО «Тюменское высшее военно-инженерное командное училище \\ имени маршала инженерных войск А.И. Прошлякова» Министерства обороны \\ Российской Федерации, Тюмень, Россия
}

Автор, ответственный за переписку: Кайгородов Михаил Дмитриевич, e-mail: heklerkox@gmail.com

\begin{abstract}
Аннотация. Существующие подходы по снижению неравномерности осадок зданий и сооружений имеют свои достоинства и недостатки. Одним из перспективных методов по снижению неравномерности осадок фундаментов мелкого заложения, в основании которых залегают слабые пылевото-глинистые грунты, является опускание здания или его части. Эффект достигается путем выбуривания вертикальных скважин в непосредственной близости от фундамента со стороны наименьших осадок. Метод. В разное время разработками методик расчета горизонтального и наклонного выбуривания скважин занимались отечественные и зарубежные ученые. Важным вопросом, при применении данной технологии, остается определение параметров бурения, влияние грунтовых характеристик и напряжённого состояния грунтов, вокруг скважины, на процесс снижения неравномерности осадки. В статье рассматривается влияние прочностных характеристик грунтов на напряжённое состояние грунтового массива вокруг скважины, а также влияние радиуса выбуриваемой скважины на формирование областей предельного состояния. Аналитическое решение основано на использовании известного соотношения для
\end{abstract}

определения напряженного состояния вокруг скважины при прессиометрических испытаниях. Из данного соотношения определяются тангенциальные и радиальные напряжения, которые затем проверяются по условию закона прочности, тем самым формируется картина напряженного состояния вокруг скважины. Результат. По представленной методике выполнены расчеты напряженного состояния грунта вокруг скважин, позволяющие рассчитывать зоны разрушения грунта и тем самым определять параметры скважин и геометрию их расположения в зависимости от поставленных целей, при регулировании осадок плитных фундаментов. Установлено, что бурение за контуром фундамента по отношению к бурению в контуре фундамента позволяет увеличить радиус зоны пластических деформаций до двух раз при одинаковых грунтовых условиях и геометрии скважины.

Ключевые слова: неравномерная осадка; крен; выбуривания грунта; фундаменты мелкого заложения; параметры бурения; манжетная технология; тангенциальные напряжения; радиальные напряжения

Данная статья доступна по лицензии Creative Commons “Attribution” («Атрибуция») 4.0 Всемирная

This article is available under the Creative Commons "Attribution" 4.0 Global License

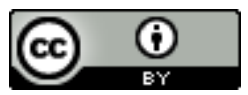




\section{Introduction}

\section{Введение}

Differential settlements of foundations during construction and operation of buildings and structures is one of the challenges which the construction industry faces [7]. Thus, cracks and distortions appear in relatively flexible buildings, and tilts - in stiff buildings and structures which are considered in the paper. The differential settlements can be caused by different reasons [13].

It is important to determine the problem and detect the reasons of differential deformations resulting in the building tilts. This helps plan the strategy for the chosen method and technology for reducing the differential settlement and bringing it to standard and (or) safe values [10]. A large number of methods used for correcting the building tilt are known; each method has its own advantages, disadvantages and limitations when used [16].

Pulatov A.P. ${ }^{1}$ pointed out that two methods of aligning the geometric position of buildings are normally used in construction: the first is the use of special mechanisms and adjustable foundations installed in the foundation-basement of the building during construction or aligning period [18; 19] the second - aligning structures without any mechanisms and structural members of foundations, but by creating extra deformations of the soil bed from smaller settlements $[1 ; 7 ; 9 ; 11]$.

None of these approaches is universal. Each methods used must be economically viable and technologically justified in terms of its effectiveness and safety [20].

When the soil bed is composed of weak silt-loam soils, typical for the south of the Tyumen Region, the method of vertical drilling-out of soil, i.e. weakening of the soil bed from minimal settlements, is one of the most promising ways to correct the spatial position of buildings and structures. Widely used horizontal drilling or drilling slightly inclined to the horizon in weak water-saturated soils, as well as in the constraint environment typical for built-up areas has significant drawbacks. It is difficult to execute the work safely in given high level of groundwater and ensure safe operation for adjacent buildings [4].

The formed areas of plastic deformations (soil destruction) around the vertical boreholes or the ones slightly inclined to the vertical, with a certain distance between them, located in the area of minimal foundation settlements is the principle difference of the proposed method from the other ones [6;8].

It should be noted that differential settlements which lead to the building tilt are almost always characterized by their unregulated state in weak silt-loam soils. Therefore, before using a particular technology, it is necessary to stabilize the

\footnotetext{
${ }^{1}$ Pulatov A.P. [Work of foundations when leveling structures by drilling horizontal and inclined wells]. Candidate thesis of technical sciences. Kiev, 1986
} 
vertical displacements of the foundation from the maximum settlements and then reduce differential settlements and thus, eliminate the tilt.

\section{Method}

\section{1. Метод}

The authors believe that destruction of soil is caused by the developed areas of plastic deformations and shears around the borehole $[2 ; 3 ; 14 ; 17]$. The main factors affecting the stress-strain state of the soil around the boreholes are as follows: physical and mechanical characteristics of the soil bed, borehole geometry and stress state in the soil bed. The influence of groundwater is not taken into account.

In general case, within the framework of the approach studied, there exist three main design cases for locating boreholes:

1. A single borehole beyond the stresses from the foundation slab (with stresses from the soil own weight).

2. A borehole in the contour of the foundation slab.

3. A borehole beyond the contour of the foundation slab.

The first design case was considered by the authors in the corresponding paper published earlier [19].

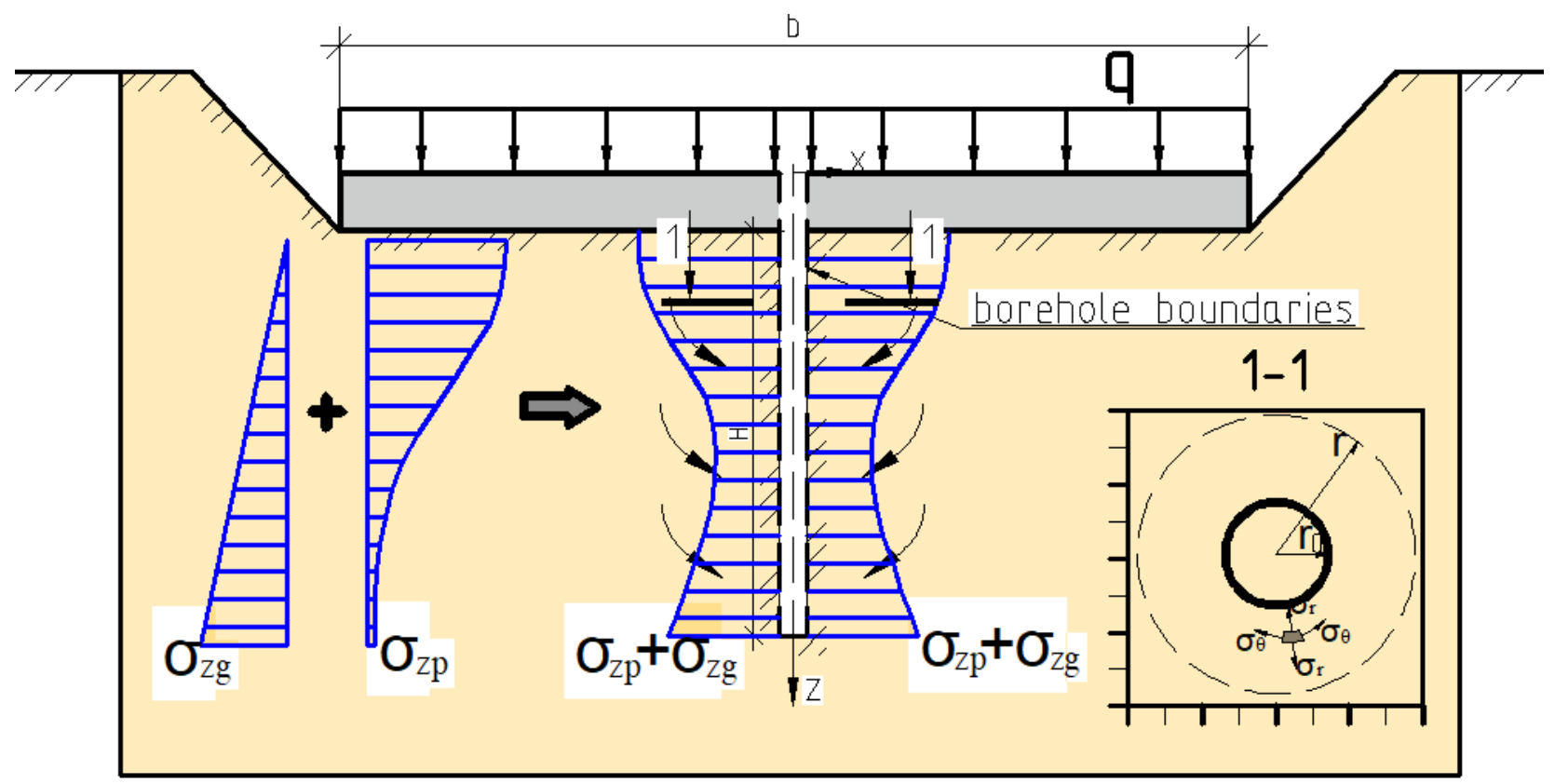

Figure 1. Design cases for locating a cylindrical borehole versus the foundation (developed by the authors)

Рисунок 1. Расчетные случаи расположения цилиндрической скважины относительно фундамента (разработано авторами) 
To formulate the problem, let us consider case 2, i.e. location of the borehole in the contour of the foundation slab. In here, stresses from the soil own weight $\left(\sigma_{g}\right)$ and stresses from the foundation slab $\left(\sigma_{p}\right)$ are taken into account (fig. 1).

An axially symmetrical scenario is used for solution of the problem for the reason that the borehole in the soil is conventionally an ideal cylindrical cavity symmetrically loaded in its height [12].

The boundary conditions are established by reference to the absence of other factors influencing the stress state of the considered soil massif, except the stress from the soil own weight and pressure from the foundation slab.

In order to determine the stress-strain state of the soil around the formed borehole, modified formulas given in the works of Ter-Martirosyan Z.G., Boldyreva G.G. $[14 ; 21]$ are used; they help evaluate the stress-strain state of the soil massif during pressure tests (1).

$$
\left.\begin{array}{l}
\sigma_{r}=\frac{\mu}{1-\mu} *\left(\gamma * z+\sigma_{z p}\right) *\left(1+\frac{r_{0}^{2}}{r^{2}}\right) \\
\sigma_{\vartheta}=\frac{\mu}{1-\mu} *\left(\gamma * z+\sigma_{z p}\right) *\left(1-\frac{r_{0}^{2}}{r^{2}}\right) \\
\mathrm{u}_{r}=\frac{\mu}{1-\mu} *\left(\gamma * z+\sigma_{z p}\right) * \frac{1+\mu}{E} * \frac{r_{0}^{2}}{r^{2}}
\end{array}\right\}
$$

where, $\sigma_{z p}=\mathrm{p}^{*} \alpha-$ stresses in soil from the foundation;

$\mathrm{P}$ - foundation pressure;

$\alpha$ - coefficient taking into account distribution of stresses in depth; it is determined according to Building Regulation (SP 22.13330.2016), Table. 5.18;

$\mathrm{z}$ - depth to determine the stress;

$\mathrm{r}$ - borehole radius;

$\mathrm{r}_{0}$ - radius of the plastic deformation area around the borehole.

The formulas (1) make it possible to determine tangential $-\sigma_{\vartheta}$ and radial $-\sigma_{r}$ stresses.

Thus, substituting the determined stresses to the strength law (2), the following formula can be obtained:

$$
\sin \varphi=\frac{\left(\sigma_{r}-\sigma_{\vartheta}\right)}{\left(\sigma_{r}+\sigma_{\vartheta}+2 * C * \operatorname{ctg} \varphi\right)}
$$

The computational program "GsMonitor" has been developed to determine the areas of the soil limit state around the borehole of a given configuration.

"GsMonitor" operation algorithm. 
It follows from the formulas (1) that the whole of parameters included can now be functions of depth, namely:

$$
\left.\begin{array}{l}
\sigma_{r}=\frac{\mu(z)}{1-\mu(z)} *\left(\gamma(z) * z+\sigma_{z p}(z)\right) *\left(1+\frac{r_{0}^{2}}{r^{2}}\right) \\
\sigma_{\vartheta}=\frac{\mu(z)}{1-\mu(z)} *\left(\gamma(z) * z+\sigma_{z p}(z)\right) *\left(1-\frac{r_{0}^{2}}{r^{2}}\right)
\end{array}\right\}
$$

In order to simplify the formula, let us denote the total value of the stressed soil in the specified depth by:

$$
s(z)=\frac{\mu(z)}{1-\mu(z)} *\left(\gamma(z) * z+\sigma_{z p}(z)\right) ; \sigma_{z p}(z)=\mathrm{P} \cdot \alpha(z)
$$

The stress from the foundation can be determined using the data given in Table 5.18, $\mathrm{SP}^{2}$.

Taking into account the formulas (1), the following formula which incorporates physical properties of the soil and geometric dimensions of the borehole is obtained:

$$
\sin \varphi(z)=\frac{S(z) \frac{r_{0}^{2}}{r^{2}}}{s(z)+c(z) * \operatorname{ctg} \varphi(z)}
$$

Thus, it is possible to determine explicitly the borehole and plasticity radii:

$$
\begin{gathered}
r_{0}^{2}=r^{2}\left(\sin \varphi+\frac{c}{S} \cos \varphi\right) \rightarrow r_{0}=f(r, z=\text { const }) \\
r^{2}=r_{0}^{2}\left(\sin \varphi+\frac{c}{S} \cos \varphi\right)^{-1} \rightarrow r=f\left(r_{0}, z=\text { const }\right)
\end{gathered}
$$

Thus, by establishing the borehole depth $z$, it is possible to calculate the values of the specified radii.

The single-valued positive solution for the depth coordinate $z$ is determined by the ratio of the functional connections dependent upon this variable. In order to determine the stress from the foundation at a specified depth, data from a two-dimensional table are needed. If bilinear interpolation of multidimensional data is used, one can record the assumed formula for the coefficient $\alpha(z)$ for values with any foundation parameters:

${ }^{2}$ SP 20.13330.2016 [Loads and impacts. Updated edition of SNiP 2.01.07-85*] (with Amendments N 1, 2)docs.cntd.ru. URL: https://docs.cntd.ru/document/456044318 (date of application: 23.03.2021). 


$$
\alpha(z)=\alpha(\xi, \eta)=\left|\begin{array}{l}
\xi=\frac{2 z}{b} ; b=\text { const } \\
\eta=\frac{L}{b} ; L=\text { const }
\end{array}\right|=\beta_{0}+\beta_{1} \xi+\beta_{2} \eta+\beta_{3} \xi \eta
$$

By establishing $z$, one can determine $(\xi, \eta)$; next, the interval boundaries, with the values of the specified variables between them, are determined. Let it be definite:

$$
\left\{\begin{array}{l}
\alpha_{11}=\alpha\left(\xi_{1}, \eta_{1}\right) \\
\alpha_{22}=\alpha\left(\xi_{2}, \eta_{2}\right) \\
\alpha_{12}=\alpha\left(\xi_{1}, \eta_{2}\right) \\
\alpha_{21}=\alpha\left(\xi_{2}, \eta_{1}\right)
\end{array} ;\left\{\begin{array}{l}
\xi_{1} \leq \xi \leq \xi_{2} \\
\eta_{1} \leq \eta \leq \eta_{2}
\end{array}\right.\right.
$$

To evaluate the indeterminate $\beta_{i}$, a system of 4 linear equations with 4 indeterminate values is obtained. Its expanded matrix is as follows:

$$
\left(\begin{array}{l}
1 \xi_{1} \eta_{1} \xi_{1} \eta_{1} \mid \alpha_{11} \\
1 \xi_{2} \eta_{2} \xi_{2} \eta_{2} \mid \alpha_{22} \\
1 \xi_{1} \eta_{2} \xi_{1} \eta_{2} \mid \alpha_{12} \\
1 \xi_{2} \eta_{1} \xi_{2} \eta_{1} \mid \alpha_{21}
\end{array}\right)
$$

Having solved it by the Jordan-Gauss method, the indeterminate dependency coefficients are obtained. When substituting the specified actual values $(\xi, \eta)$, the required value of the coefficient and the values of stresses from the foundation at a given depth are obtained ${ }^{3}[5]$.

Next, the functions related to the above dependencies are obtained for soil parameters and stresses. Let us pay particular attention to the real possibility for the equation to be solved (8). Let us rewrite it as follows:

$$
\sin \varphi+\frac{c}{S} \cos \varphi=\frac{r_{0}^{2}}{r^{2}}
$$

Under the condition:

$$
\delta=\frac{r_{0}^{2}}{r^{2}} \leq 1
$$

Minimizing the trigonometric part of the equation as a formula with phase, we obtain:

$$
\sqrt{1+\left(\frac{c}{S}\right)^{2}} \sin (\varphi+\theta)=\delta ; \operatorname{tg} \theta=\frac{c}{s}
$$

\footnotetext{
${ }^{3}$ Pulatov A.P. [Work of foundations when leveling structures by drilling horizontal and inclined wells]. Candidate thesis of technical sciences. Kiev, 1986.
} 
It follows that:

$$
\sin (\varphi+\theta)=\frac{\delta}{\sqrt{1+\left(\frac{c}{s}\right)^{2}}} \rightarrow \frac{\delta}{\sqrt{1+\left(\frac{c}{s}\right)^{2}}} \leq 1
$$

Taking into account that the expanded formula can be changed in an arbitrary way depending on the depth, namely:

$$
\frac{\delta}{\sqrt{1+\left(\frac{c(z)}{s(z)}\right)^{2}}} \leq 1
$$

One can come to the conclusion that the last inequality is true for any dependence on distance due to the above assumptions. Thus, the solution is relevant for any diameter and depth of the borehole, but it should be noted that it may not fall within the specified distance interval.

\section{Results}

\section{2. Результат}

Let us consider the software algorithm using a test example.

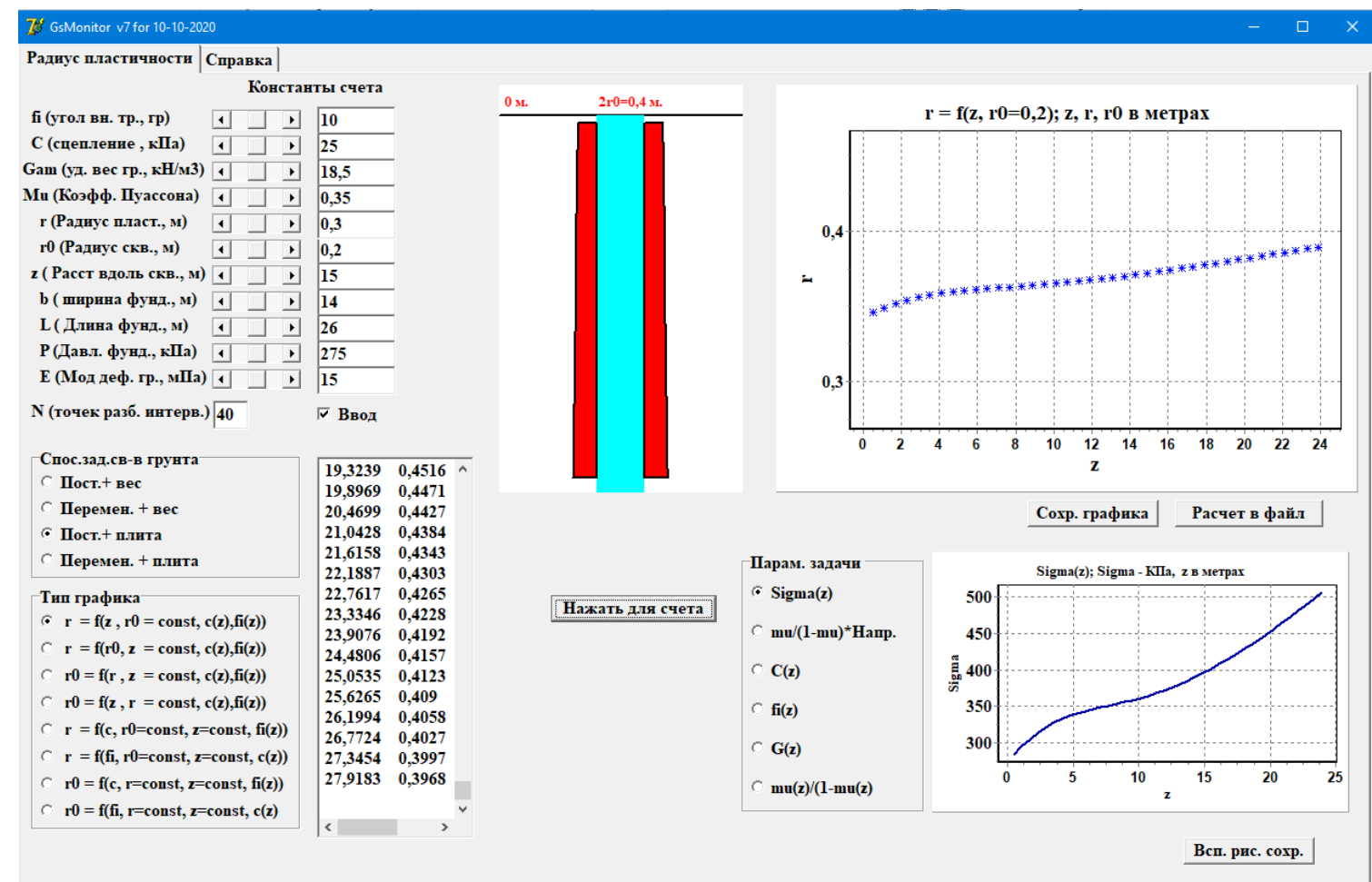

Figure 2. GsMonitor Dialog Box (developed by the authors)

Рисунок 2. Диалоговое окно программы GsMonitor (разработано авторами) 
Initial data and boundary conditions:

1. Borehole: located vertically in the contour of the foundation slab, $\mathrm{d}=0.4 \mathrm{~m}$; the borehole is affected by stresses from the foundation slab and the soil own weight.

2. Soil conditions: homogeneous clay soil possessing the following characteristics $\varphi=10^{0}, \quad \mathrm{c}=25 \mathrm{kPa}, \quad \gamma=18.5 \mathrm{kN} / \mathrm{m}^{3}, \quad \mathrm{E}=15 \mathrm{MPa}$, groundwater is not considered.

3. Foundation: pressure under its footing $\mathrm{P}=275 \mathrm{kPa}$, slab dimensions bxL $(14 \times 26 \mathrm{~m})$.

The soil characteristics, radius of the borehole, foundation geometry and pressure under the foundation footing are displayed in the dialog box in the upper left corner (fig. 2). The required design diagram and the type of graph are selected below. The calculations being completed, an illustration appears in the center of the window: a borehole (blue) and areas of plastic deformations of soil (red) around it. The selected type of graph is displayed in the upper right corner; e.g. Figure 4 shows the radius of the plastic deformation area versus the depth. Based on the scenario obtained for the stress state around the borehole, the parameters of drilling-out, i.e. spacing, length and diameter of the boreholes can be chosen as the initial data for the technology of weakening in order to eliminate the building tilt.

\section{Design case}

\section{3. Расчетный случай}

A block of flats located in the city of Tyumen in Belyaeva Street can serve an example of significant differential settlements. The building was constructed in 2014-2016. The building consists of two blocks of 9 and 14 floors respectively [19].

The foundation slabs of both blockss are made of mass concrete B30, $1.0 \mathrm{~m}$ in thickness. The outer walls of the substructure are made of FBS blocks, $600 \mathrm{~mm}$ in thickness; the inner walls are $500 \mathrm{~mm}$ in thickness. The outer walls of the superstructure are made of insulated brick, with a total thickness of $820 \mathrm{~mm}$; the inner walls are $510 \mathrm{~mm}$ in thickness.

Further, the 14-floor block is going to be considered as it suffers from the greatest differential settlement.

The average pressure under the foundation slab footing from the design load is $-p^{p}=285 \mathrm{kPa}$. 


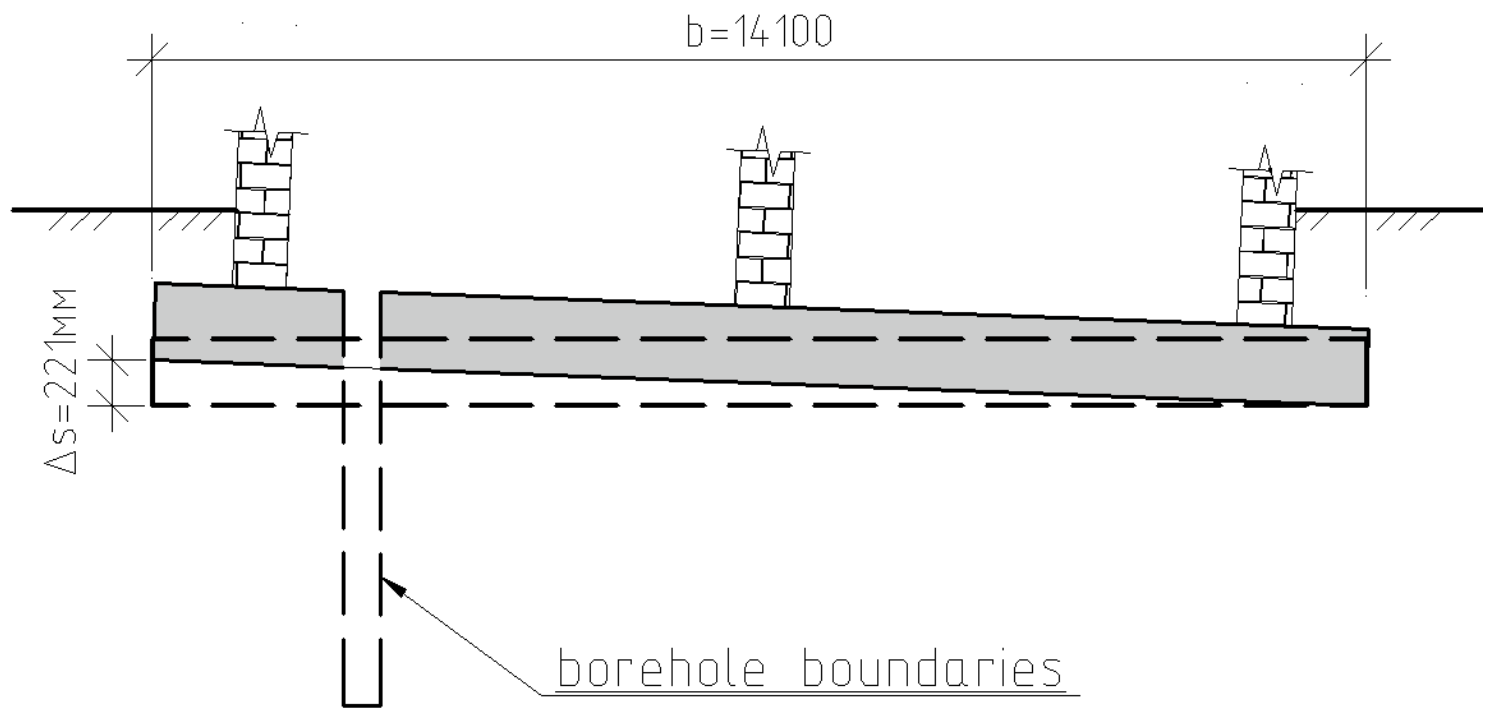

Figure 3. Building section (developed by the authors)

Рисунок 3. Разрез здания (разработано авторами)

After the results of geodetic survey, the deviation from the facade vertical of the 14-floor block of the building has been $660 \mathrm{~mm}$ with the limit value after Building Regulation $-9 \mathrm{~cm}$, the relative difference in settlements has reached the value $\quad \Delta \mathrm{s} / \mathrm{L}=0.019>[\Delta \mathrm{s} / \mathrm{L}]=0.0024 \quad \mathrm{SP} 22.13330 .2016 \quad$ (table D1). The engineering-geological characteristics of the soil bed are given in table 1.

Table 1 / Таблица 1

\section{Physical and mechanical characteristics of foundation soils}

\section{Физико-механические характеристики грунтов основания}

\begin{tabular}{|c|c|c|c|c|c|c|}
\hline \begin{tabular}{|c|}
$\begin{array}{c}\text { Layer number } \\
\text { № слоя }\end{array}$ \\
\end{tabular} & $\begin{array}{l}\text { Thickness, m } \\
\text { Мощность, м }\end{array}$ & $\begin{array}{c}\text { Soils } \\
\text { Грунты }\end{array}$ & $\begin{array}{l}E, M P a \\
\text { Е, МПа }\end{array}$ & $\begin{array}{l}\gamma, k N / m^{3} \\
\gamma, \kappa H / M^{3}\end{array}$ & $\begin{array}{l}c, k P a \\
\mathrm{c}, \mathrm{\kappa} \Pi а\end{array}$ & $\begin{array}{c}\varphi \text {, degrees } \\
\varphi, \text { град }\end{array}$ \\
\hline 1 & 2.1 & $\begin{array}{l}\text { Soft-plastic loam } \\
\text { Суглинок мягкопла-стичный }\end{array}$ & 8.4 & 19.5 & 18 & 12 \\
\hline 2 & 4.7 & $\begin{array}{l}\text { Fluid and fluid-plastic loams } \\
\text { Суглинок текучий и текучепластичный }\end{array}$ & 2.7 & 17.8 & 10 & 10 \\
\hline 3 & 4.6 & $\begin{array}{l}\text { Interlacing of fine sands with sandy loams } \\
\text { and loams } \\
\text { Переслаивание мелкого песка с супесью и } \\
\text { суглинком }\end{array}$ & 20.6 & 19.6 & 9 & 27 \\
\hline 4 & 11.5 & $\begin{array}{l}\text { Fine silty sands with interlayers of sandy } \\
\text { loams and loams } \\
\begin{array}{l}\text { Песок мелкий пылеватый с прослоями } \\
\text { супесей и суглинка }\end{array}\end{array}$ & 29 & 20.6 & 3 & 31 \\
\hline
\end{tabular}

Developed by the authors / Разработано авторами

To eliminate the excess differential settlements, it has been decided to drill out vertical boreholes in the contour of the foundation slab from the minimal settlements. In here, rotary core drilling has been carried out in the foundation slab followed by drilling-out of boreholes in the soil bed (fig. 3). The plasticity areas by depth in the given conditions have been determined for further choice of spacing and depth of the boreholes by modeling in the "GsMonitor" software. 
According to the algorithm given above, the stress-strain state around the borehole is illustrated in (fig. 4).

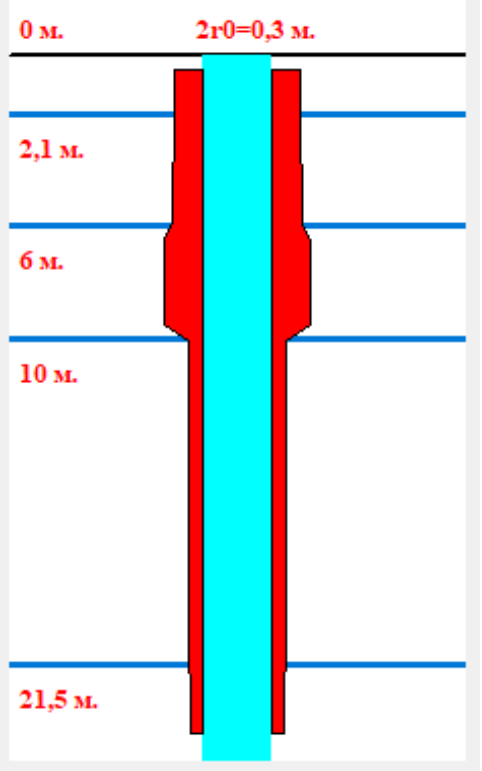

a

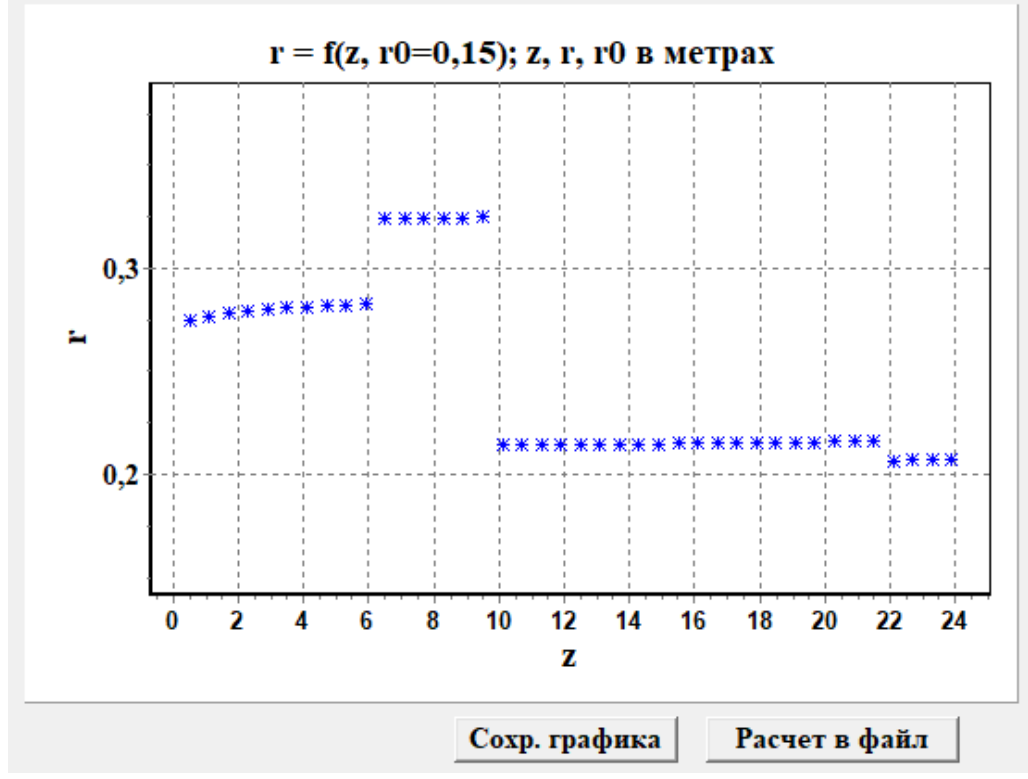

$\mathrm{b}$

Figure 4. a) Areas of plastic deformation around the borehole (in red);

b) Graph of the plastic area radius versus the borehole depth (developed by the authors)

Рисунок 4. а) Зоны пластических деформаций вокруг скважсины (красным иветом); b) График зависимости радиуса зоны пластичности от глубины скважины (разработано авторами)

Next, the data obtained have been analyzed for the spacing and depth of drilling to be chosen. As can be seen in fig. 4, the area of plastic deformation decreases sharply, i.e. by $34 \%$ from a depth of 10 meters from the level of the foundation footing. This is due to two factors: the changed physical and mechanical characteristics of soils at the stratum and the decreased effect of stresses in the soil from the foundation slab. Thus, it can be concluded that the effective drilling depth is $\mathrm{z}=10 \mathrm{~m}$. Taking into account the collapsible borehole walls and filling them with soil, the intersection of plastic deformation areas around the boreholes is required to be considered for the spacing in the drilling procedure [2].

The maximum radius of the plastic deformation area is $\mathrm{r}=0.32 \mathrm{~m}$ in the design case. Here, the borehole spacing equal to two radii of plasticity $2 * \mathrm{r}=0.64 \mathrm{~m}$ is obtained. Yet, in order to ensure the slab strength, the drilling frequency has been $2 \mathrm{~m}$. This frequency of drilling-out in the contour of the foundation slab has been insufficient for correcting such a significant building tilt. The boreholes are slowly "tightened" with soil retaining stability of their walls. The data of monitoring confirm this (fig. 5).

Thus, 4 cycles of drilling-out have resulted in the average extra settlement to be $S_{\text {extra }}=4 \mathrm{~cm}$. 
Data on actual settlements of geodetic marks for the 14-floor block Date

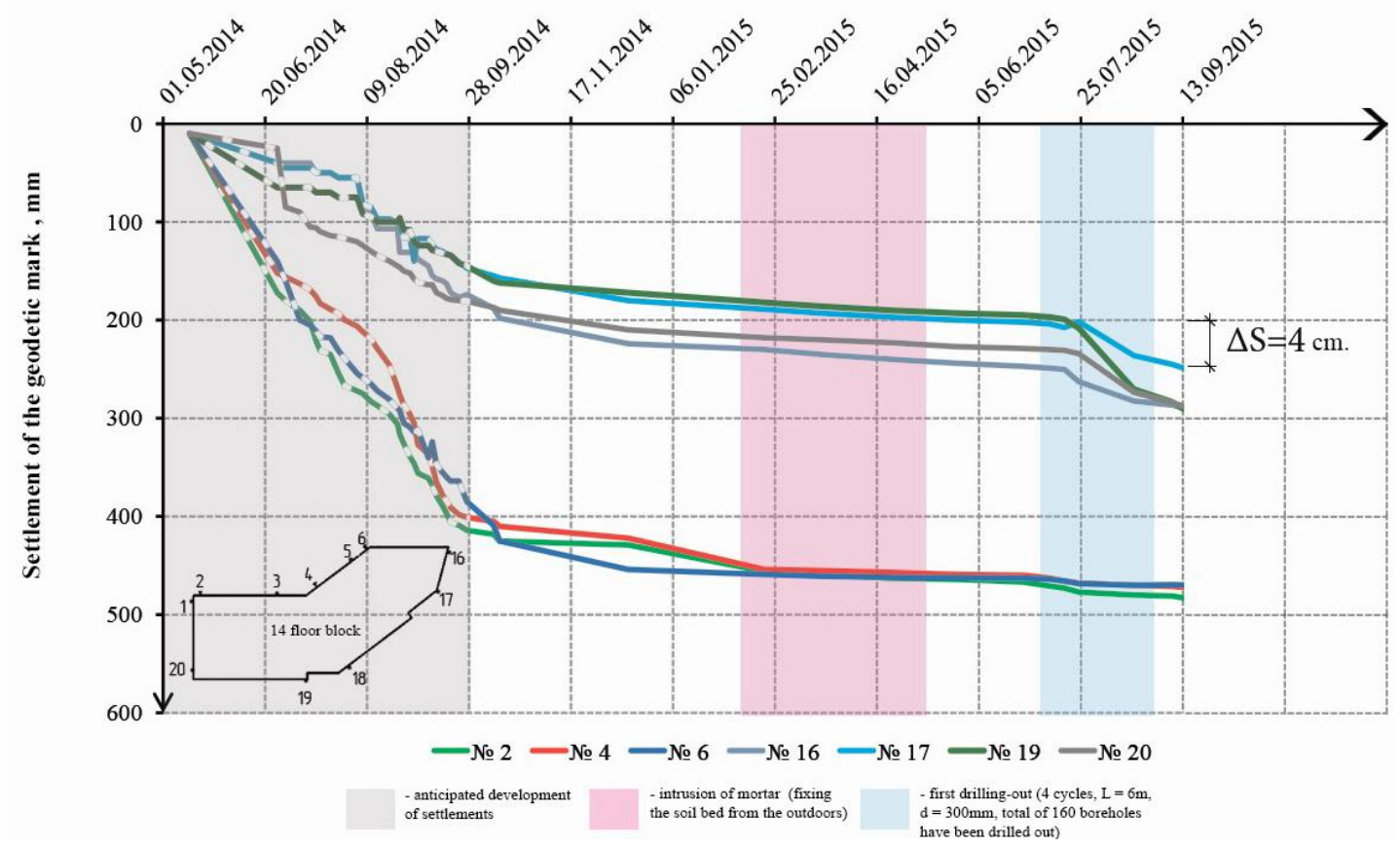

Figure 5. Settlements monitored at the construction facility in Tyumen during the performance of work aimed at reducing the differential settlements (developed by the authors)

Рисунок 5. Мониторинг осадок на объекте в г. Тюмени при производстве работ по снижению неравномерности осадок (разработано авторами)

III - design case

In the third case, the location of the well relative to the foundation was considered, in the same soil conditions. So in the second case, the well was located in the contour of the foundation slab, and in the third design case outside the contour of the foundation. Well $\mathrm{d}=0.3 \mathrm{~m}$ was taken for comparative analysis. and length $\mathrm{z}=25 \mathrm{~m}$, foundation width $\mathrm{b}=14 \mathrm{~m}$, clay soil with the following characteristics: $\mathrm{c}=28 \mathrm{kPa}, \varphi=220$. The pressure under the sole was taken from 100 to $300 \mathrm{kPa}$, with a step of $100 \mathrm{kPa}$. The influence of groundwater on the stress state of the well was not considered. 


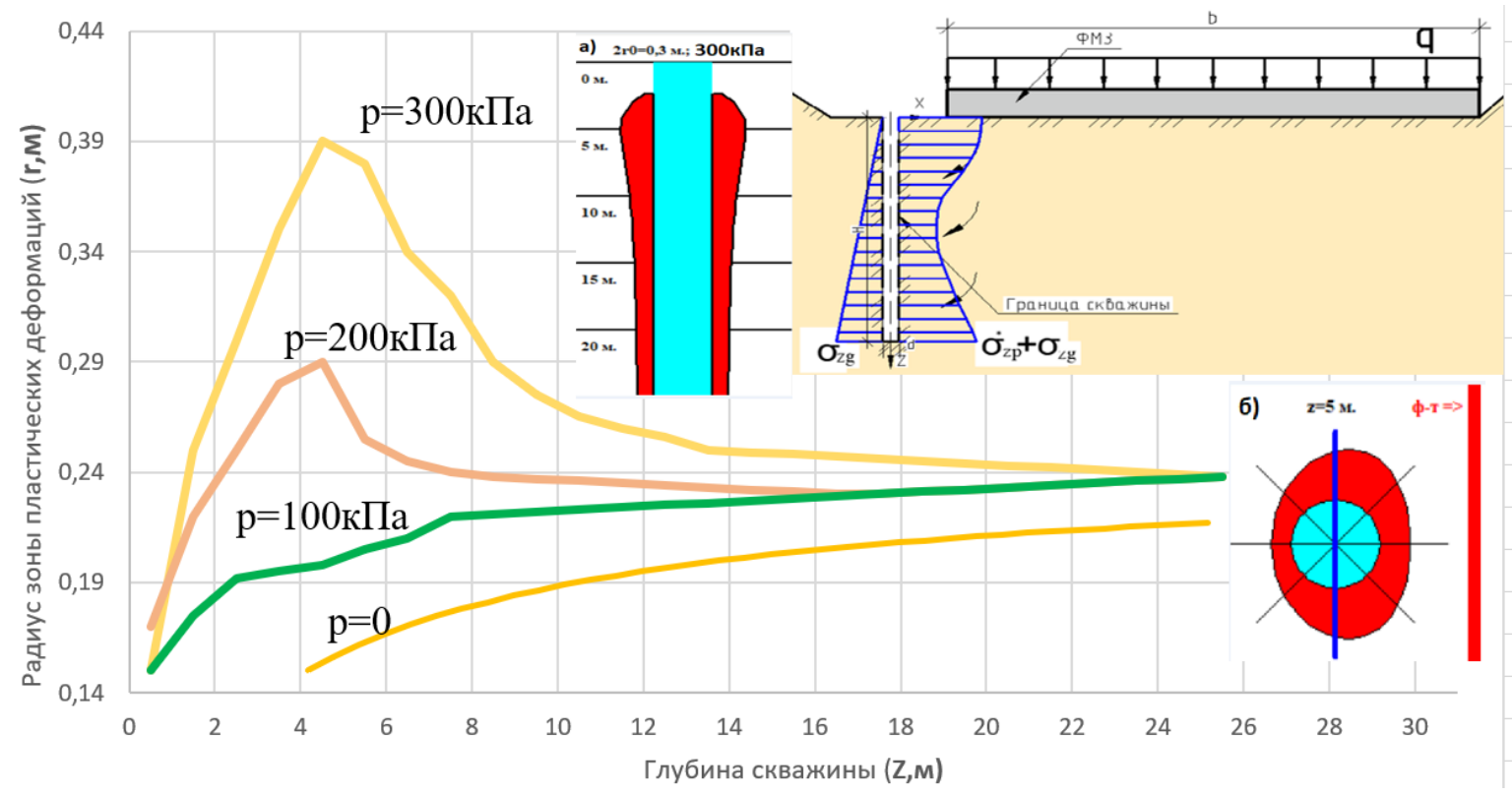

Figure 6. Graph of dependence of the radius of plastic deformation zones in depth for a well located in the foundation contour: (a) GsMonitor program; the picture of plastic deformation zones (in red) around the well at a pressure of $300 \mathrm{kPa}$ under the basement base corresponds to the yellow graph (developed by the authors)

Рисунок 6. График зависимости радиуса зон пластических деформаций по глубине для скважины, расположенной в контуре фундамента: а) программа

GsMonitor; картина зон пластических деформаций (красным ияветом) вокруг скважсины при давлении под подошвой фундамента 300 кПа, соответствует желтому графику (разработано авторами)

From the graph in figure 2, it follows that an increase in pressure under the basement base leads to an increase in plastic zones around the well, this factor is especially significant when drilling out a well outside the basement contour, that is, with its asymmetric loading. With the same initial data (soil characteristics and borehole geometry), moving the borehole out from under the foot of the foundation gives an average increase in the zone of plastic deformation by a factor of two. It should be noted that moving the well beyond the foundation contour forms asymmetric zones of plastic deformation around the well.

Thus, it should be stated that the third design case is the most effective from the point of view of destruction of the soil around the well and the achievement of the ultimate goal - controlled additional foundation settlement and roll correction.

Thus, it should be stated that the third design case is the most effective from the point of view of destruction of the soil around the well and the achievement of the ultimate goal - controlled additional foundation settlement and roll correction.

As a criterion for the effectiveness of the use of drilling technology, the following condition is accepted:

$$
\mathrm{V}_{\mathrm{sp}} \geq \mathrm{V}_{\mathrm{h}}
$$

where, Vsp - volume of soil falling into the zone of plastic deformation; 
$\mathrm{Vh}$ - well volume.

So, if the condition is met and the volume of the soil exceeds the volume of the well, then we can assume that the well is completely filled and its drilling has maximum efficiency.

As the initial data, homogeneous soil is used; in one case, the adhesion of the soil $\mathrm{C}=25 \mathrm{kPa}$ and the angle of internal friction changes in the range from 0 to 30 degrees, in the other case, the angle of internal friction $\varphi=200$ is fixed and the adhesion of the soil changes from 0 to $30 \mathrm{kPa}$. The rest of the characteristics are taken constant:

- specific gravity of soil $\gamma=18 \mathrm{kN} / \mathrm{m}^{3}$;

- deformation modulus $\mathrm{E}=6 \mathrm{MPa}$;

- $\mathrm{Skr}=1.2 \mathrm{~m}$ - distance from the center of the well to the edge of the foundation;

- $\mathrm{D}=0.3 \mathrm{~m}$ - borehole diameter;

- $\mathrm{P}=100 \mathrm{kPa}$ - pressure under the sole.

The method of correcting the tilts in buildings and structures by drilling-out of soil is promising and, in many cases, effective. Obviously, it is simpler and less labor-consuming than other technologies. However, the results obtained have revealed that drilling in the contour of the foundation slab under axially symmetrical loading does not lead to significant development of plastic deformation areas in the soil around boreholes.

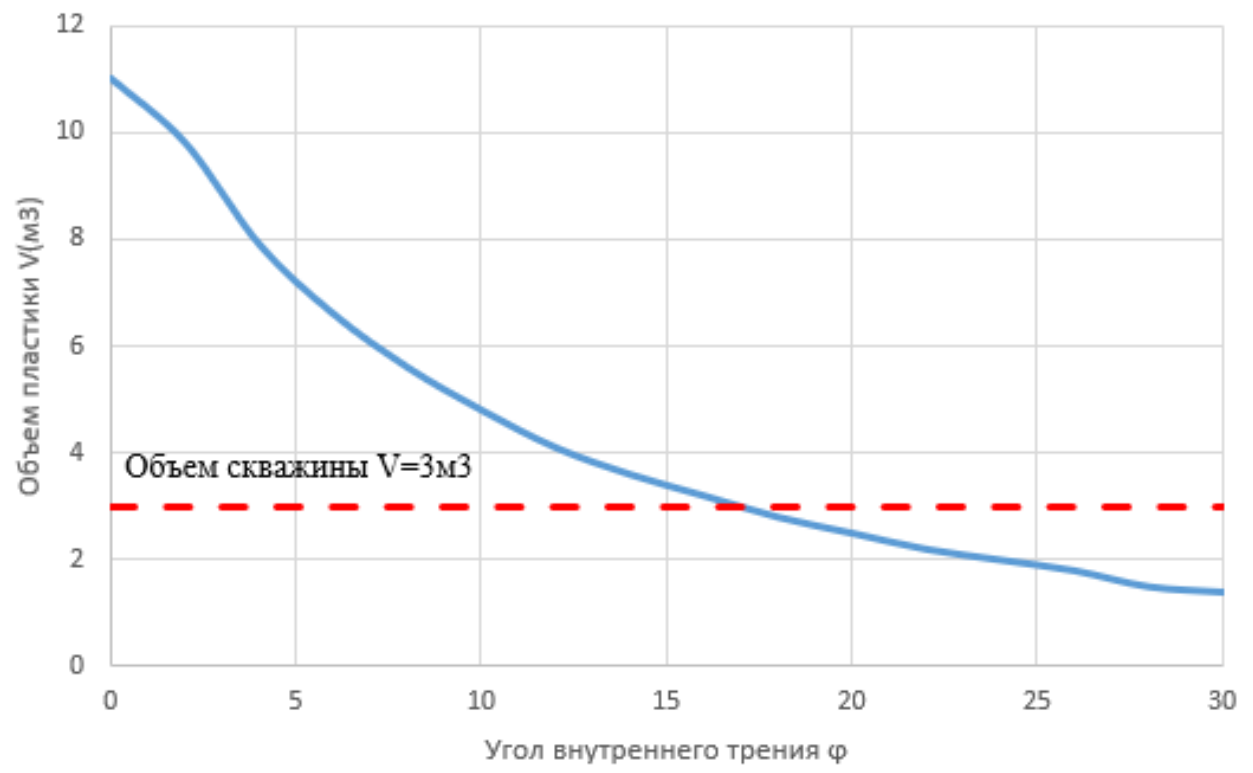

Figure 7. Graph of the dependence of the volume of soil in a plastic state on the angle of internal friction (developed by the authors)

Рисунок 7. График зависимости объёма грунта в пластическом состоянии от угла внутреннего трения (разработано авторами) 


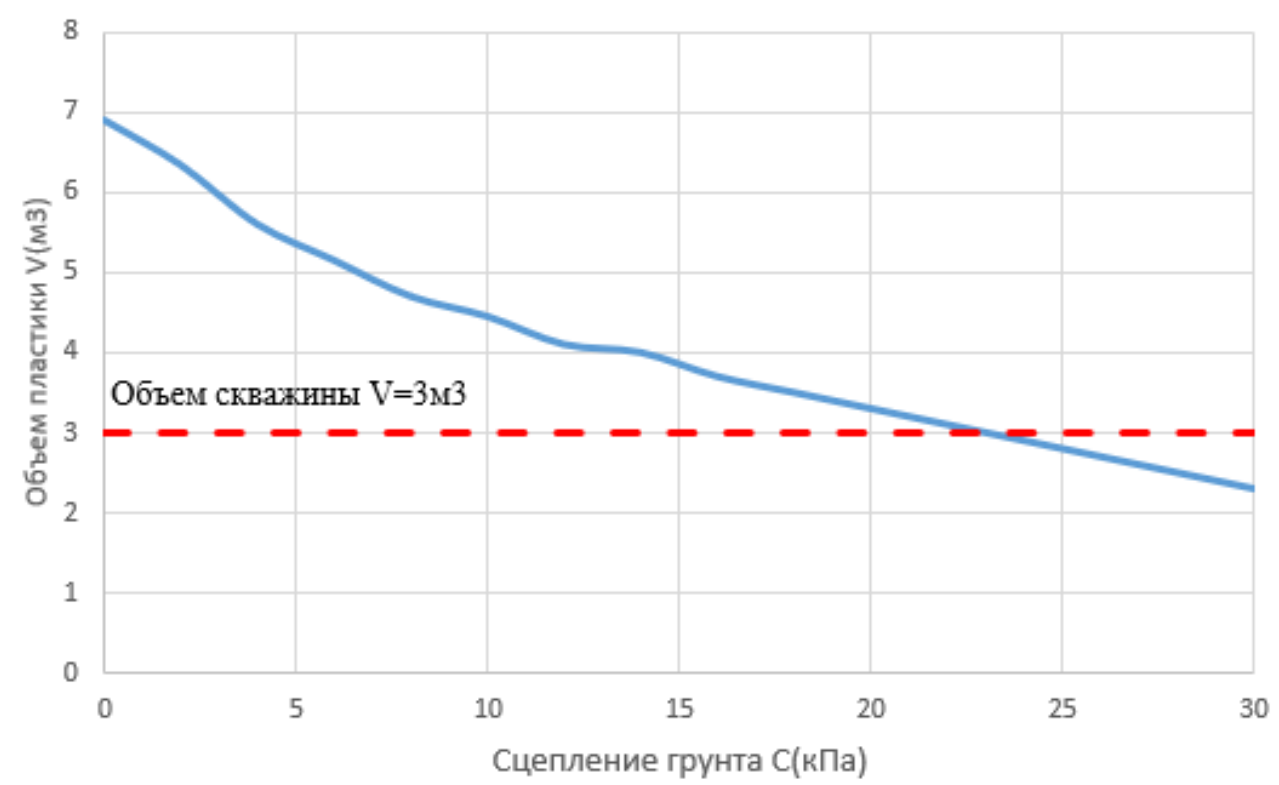

Figure 8. Graph of the dependence of the volume of soil in a plastic state on the angle of internal friction (developed by the authors)

Рисунок 8. График зависимости объёма грунта в пластическом состоянии от угла внутреннего трения (разработано авторами)

Besides, this does not lead to destruction of their walls and filling the boreholes with soil. It has been theoretically demonstrated with the developed software "GsMonitor" and the results of geotechnical monitoring at a built block of flats. To improve efficiency, it is necessary to design boreholes with a small spacing; this can significantly weaken the strength of the foundation slab and is economically viable.

The boreholes located beyond the contour of the foundation slab will probably increase the effectiveness of the proposed method of vertical drilling-out of soil. The asymmetric stress state in the soil massif around the borehole is created for spreading the areas of plastic shear deformation (destruction) of soil.

\section{Conclusion}

\section{Выводы}

1. One of the most effective ways to eliminate complex non-stabilizing heels of multi-storey buildings on slab foundations in conditions of weak water-saturated silty-clayey soils is a combined technology of cementation using lip technology on the side of the roll and weakening of the base by drilling vertical wells from the opposite side with subsequent consolidation.

2. Drilling of wells must be carried out along the foundation slab behind its contour, in order to form an asymmetric stress state of the soil around the wells, with a decrease in the spacing of the wells in the corner zones. With a certain choice of the pitch and diameter of the wells, zones of overlapping plastic deformations 
appear around the wells and the surfaces of deep displacements of the base towards the wells are formed with their filling and, as a result, the trim of the aboveground part is corrected.

3. The applied method of tilting correction must be carried out according to the previously completed design documentation, with the obligatory adjustment of the technology in the process of work on the basis of continuously conducted geodetic control and the forecast of possible scenarios of the object's behavior, with previously worked out emergency solutions.

4. For the control parameter of drilling out, i. E. technological criterion, the condition of approximate equality of the total volume of drilled soil and the volume of the base wedge to be removed can be adopted to correct the geometric inclination of the building.

5. In conditions of weak water-saturated soils, it is recommended to stop work on weakening the base, when the residual heel is within the limits specified in the current standards, taking into account the time required for the final fixing of the base, in order to avoid the appearance of counter-roll. 


\section{REFERENCES}

1. Yue Q., Zhang X. Experimental Study on the Stress Distribution and Failure Mode of the Holes for Underexcavation in Building Rectification. Geo-Congress 2020: Engineering, Monitoring, and Management of Geotechnical Infrastructure. Minneapolis: American Society of Civil Engineers; 2020. p. 269-278. Available at: https://ascelibrary.org/doi/10.1061/9780784482797.026 (accessed 20th March 2021). (In Eng.) DOI: https://doi.org/10.1061/9780784482797.026.

2. Abelev M.Y., Averin I.V., Karally D.L. Problems of Engineering Investigations on Territories with Gas-Generating Soil. Soil Mechanics and Foundation Engineering. 2020; 57(3): 252-255. (In Eng.) DOI: https://doi.org/10.1007/s11204-020-09662-3.

3. Fioravante V., Giretti D., Jamiolkowski M. Liquefaction resistance of partially saturated soils from CPTs. In: Silvestri \& Moraci (Eds). Earthquake Geotechnical Engineering for Protection and Development of Environment and Constructions. Rome: Associazione Geotecnica Italiana; 2019. p. 2404-2411. Available at: https://iris.unife.it/retrieve/handle/11392/2405098/148478/ch241.pdf (accessed 20th March 2021). (In Eng.).

4. Sorochan E.A., Zotov M.V. Interaction between Foundation and Soil Bed when Buildings Are Leveled with Jacks. Soil Mechanics and Foundation Engineering. 2004; 41(3): 89-93. (In Eng.) DOI: https://doi.org/10.1023/B:SMAF.0000040186.12389.a1.

5. Burland J.B., Jamiolkowski M., Viggiani C. The Stabilisation of the Leaning Tower of Pisa. Soils and Foundations. 2003; 43(5): 63-80. (In Eng.) DOI: https://doi.org/10.3208/sandf.43.5_63.

6. Burland J.B., Jamiolkowski M., Viggiani C. Underexcavating the Tower of Pisa: Back to Future. Geotechnical Engineering Journal of the SEAGS \& AGSSEA. 2015; 46(4): 126135a. Available at: https://www.researchgate.net/publication/286443729_Underexcavating the_Tower_of_Pisa_Back_to_Future (accessed 20th March 2021). (In Eng.).

7. Abelev M.Yu., Krutov V.I. Leveling the Tilts of a Tenement Building Founded on Loess Soils Prone to Slump-Type Settlement by Regular Wetting. Soil Mechanics and Foundation Engineering. 2000; 37(5): 159-164. (In Eng.) DOI: https://doi.org/10.1023/A:1005260318917.

8. Pronozin, Y.A., Kiselev, N.Y., Melnikov, R.V., Stepanov, M.A. Geotechnical support for building construction in the changed basic design considerations of the superstructure. 16th Asian Regional Conference on Soil Mechanics and Geotechnical Engineering (16ARC), October 14-18, 2019. Taipei: Chinese Taipei Geotechnical Society; 2020. p. RGS-007. (In Eng.).

9. Fiorentino G., Lavorato D., Quaranta G., Pagliaroli A., Carlucci G., Nuti C., et al. Numerical and experimental analysis of the leaning Tower of Pisa under earthquake. Procedia Engineering. 2017; 199: 3350-3355. (In Eng.) DOI: https://doi.org/10.1016/j.proeng.2017.09.559.

10. Pronozin Y.A., Epifantseva L.R., Kajgorodov M.D. Structural safety of buildings in excess values of differential settlements. IV International Conference on Safety Problems of Civil Engineering Critical Infrastructures 4-5 October 2018. Ekaterinburg: IOP Publishing Ltd; 2019. p. 12013. Available at: https://iopscience.iop.org/article/10.1088/1757899X/481/1/012013 (accessed 23rd March 2021). (In Eng.) DOI: https://doi.org/10.1088/1757-899X/481/1/012013. 
11. Chen Yj., Zhang X. Analytical Plastic Solution Around Soil-Digging Holes for Inclined Building and its Application. International Journal of Civil Engineering. 2019; 17(2): 245252. (In Eng.) DOI: https://doi.org/10.1007/s40999-017-0230-7.

12. Ovando-Shelley E., Santoyo-Villa E., Hernández J. Mexico City’s Metropolitan Cathedral and Sagrario Church 13 Years After Underexcavation and Soil Hardening. International Journal of Architectural Heritage. 2016; 10(2-3): 346-359. (In Eng.) DOI: https://doi.org/10.1080/15583058.2015.1113331.

13. Ibragimov M.N. Settlement stabilization of a reconstructed building. Soil Mechanics and Foundation Engineering. 2011; 47(6): 236-240. (In Eng.) DOI: https://doi.org/10.1007/s11204-011-9115-y.

14. Ovando-Shelley E., Santoyo E. Underexcavation for Leveling Buildings in Mexico City: Case of the Metropolitan Cathedral and the Sagrario Church. Journal of Architectural Engineering. 2001; 7(3): 61-70. (In Eng.) DOI: https://doi.org/10.1061/(ASCE)1076$\underline{0431(2001) 7: 3(61) \text {. }}$

15. Mishra S.R., Bhatta D.P., Dash J.K., Makinde O.D. A Semi-Analytical Approach to Time Dependent Squeezing Flow of $\mathrm{Cu}$ and Ag Water-Based Nanofluids. Defect and Diffusion Forum. 2019; 393: 121-137. (In Eng.) DOI: https://doi.org/10.4028/www.scientific.net/DDF.393.121.

16. Ter-Martirosyan Z.G., Angelo G.O., Ter-Martirosyan A.Z. The incompressible pile draft and bearing capacity when interacting with surrounding and underlying soils, taking into account their linear and elastic-plastic properties. International Scientific Conference "Construction and Architecture: Theory and Practice of Innovative Development" 1-5 October 2019, Kislovodsk, Russian Federation. Kislovodsk: IOP Publishing Ltd; 2019. p. 22041. Available at: https://iopscience.iop.org/article/10.1088/1757-899X/698/2/022041 (accessed 23rd March 2021). (In Eng.) DOI: https://doi.org/10.1088/1757899X/698/2/022041.

17. Barvashov V.A., Boldyrev G.G. Sensitivity of structures and geological data. In: M. Papadrakakis, M. Fragiadakis (eds.). 6th ECCOMAS Thematic Conference on Computational Methods in Structural Dynamics and Earthquake Engineering, Rhodes Island, Greece, 15-17 June 2017. Rhodes Island: National Technical University of Athens (NTUA); $2017 . \quad$ p. 4634-4644. Available at: https://www.eccomasproceedia.org/conferences/thematic-conferences/compdyn-2017/5749 (accessed 23rd March 2021). (In Eng.) DOI: https://doi.org/10.7712/120117.5749.17068.

18. Ter-Martirosyan A.Z., Ter-Martirosyan Z.G., Sidorov V.V. Numerical simulation of the structures bases stress-strain state taking into account the time factor. VII International Symposium Actual Problems of Computational Simulation in Civil Engineering 1-8 July 2018, Novosibirsk, Russian Federation. Novosibirsk: IOP Publishing Ltd; 2018. p. 12094. Available at: https://iopscience.iop.org/article/10.1088/1757-899X/456/1/012094 (accessed 28th March 2021). (In Eng.) DOI: https://doi.org/10.1088/1757-899X/456/1/012094.

19. Bartelletti R., Fiorentino G., Lanzo G., Lavorato D., Marano G.C., Monti G., et al. Behavior of the Leaning Tower of Pisa: Analysis of Experimental Data from Structural Dynamic Monitoring. Applied Mechanics and Materials. 2016; 847: 445-453. (In Eng.) DOI: https://doi.org/10.4028/www.scientific.net/AMM.847.445. 
20. Li L., Hagan P.C., Saydam S., Hebblewhite B., Zhang C. A Laboratory Study of Shear Behaviour of Rockbolts Under Dynamic Loading Based on the Drop Test Using a Double Shear System. Rock Mechanics and Rock Engineering. 2019; 52(9): 3413-3429. (In Eng.) DOI: https://doi.org/10.1007/s00603-019-01776-X.

21. Wang X., Zhang X., Shi S., Liu L. The application research of comprehensive landing method during the rectification for the brick-concrete buildings in soft soil area. World Journal of Engineering. 2015; 12(4): 375-382. (In Eng.) DOI: https://doi.org/10.1260/1708$\underline{5284.12 .4 .375 .}$.

22. Yune C.Y., Olgun C.G. Analysis of consolidation settlement of normally consolidated soil by layering under 3D conditions. KSCE Journal of Civil Engineering. 2016; 20(6): 22802288. (In Eng.) DOI: https://doi.org/10.1007/s12205-015-0171-0.

23. Sert S., Kılıç A.N. Numerical Investigation of Different Superstructure Loading Type Effects in Mat Foundations. International Journal of Civil Engineering. 2016; 14(3): 171180. (In Eng.) DOI: https://doi.org/10.1007/s40999-016-0013-6.

Information about the authors:

Yakov A. Pronozin — Industrial University of Tyumen, Tyumen, Russia, e-mail: pronozinja@gmail.com

ORCID: https://orcid.org/0000-0002-6173-2796

РИНЦ: https://elibrary.ru/author_profile.asp?id=415568

SCOPUS: https://www.scopus.com/authid/detail.url?authorId=55390829400

Mikhail D. Kajgorodov — Industrial University of Tyumen, Tyumen, Russia, e-mail: heklerkox@ gmail.com ORCID: https://orcid.org/0000-0002-4671-5541

РИНЦ: https://elibrary.ru/author_profile.asp?id=962374

SCOPUS: https://www.scopus.com/authid/detail.url?authorId=57208104250

Aleksandr D. Gerber — «Marshal of Engineering Troops A.I. Proshlyakov Higher Military Engineering Command School of Tyumen» Ministry of Defense of the Russian Federation, Tyumen, Russia, e-mail: gerber_a@mail.ru ORCID: https://orcid.org/0000-0002-9611-5659

РИНЦ: https://elibrary.ru/author_profile.asp?id=296806

Submitted: 25th May 2021. Revised: 23rd July 2021. Published online: 6th August 2021. 


\section{ЛИТЕРАТУРА}

1. Yue Q. Experimental Study on the Stress Distribution and Failure Mode of the Holes for Underexcavation in Building Rectification / Q. Yue, X. Zhang. - DOI https://doi.org/10.1061/9780784482797.026 // Geo-Congress 2020: Engineering, Monitoring, and Management of Geotechnical Infrastructure / Миннеаполис: American Society of Civil Engineers, 2020. - C. 269-278. — URL: https://ascelibrary.org/doi/10.1061/9780784482797.026 (дата обращения: 20.03.2021).

2. Abelev M.Y. Problems of Engineering Investigations on Territories with Gas-Generating Soil / M.Y. Abelev, I.V. Averin, D.L. Karally. — DOI https://doi.org/10.1007/s11204-02009662-3 // Soil Mechanics and Foundation Engineering. — 2020. — T 57, № 3. - C. 252255. - URL: https://link.springer.com/article/10.1007/s11204-020-09662-3 (дата обращения: 20.03.2021).

3. Fioravante V. Liquefaction resistance of partially saturated soils from CPTs / V. Fioravante, D. Giretti, M. Jamiolkowski // Earthquake Geotechnical Engineering for Protection and Development of Environment and Constructions / Рим: Associazione Geotecnica Italiana, 2019. - C. 2404-2411. - URL: https://iris.unife.it/retrieve/handle/11392/2405098/148478/ch241.pdf (дата обращения: 20.03.2021).

4. Sorochan E.A. Interaction between Foundation and Soil Bed when Buildings Are Leveled with Jacks / E.A. Sorochan, M.V.Zotov. - DOI https://doi.org/10.1023/B:SMAF.0000040186.12389.a1 // Soil Mechanics and Foundation Engineering. - 2004. - T 41, № 3. - C. 89-93. - URL: https://link.springer.com/article/10.1023\%2FB\%3ASMAF.0000040186.12389.a1 （дата обращения: 20.03.2021).

5. Burland J.B. The Stabilisation of the Leaning Tower of Pisa / J.B. Burland, M. Jamiolkowski, C. Viggiani. - DOI https://doi.org/10.3208/sandf.43.5_63 // Soils and Foundations. - 2003. - T 43, № 5. - C. 63-80. — URL: https://www.sciencedirect.com/science/article/pii/S0038080620307502 (дата обращения: 20.03.2021).

6. Burland J.B. Underexcavating the Tower of Pisa: Back to Future / J.B. Burland, M. Jamiolkowski, C. Viggiani // Geotechnical Engineering Journal of the SEAGS \& AGSSEA. - 2015. - T 46, № 4. - C. 126-135a. - URL: https://www.researchgate.net/publication/286443729_Underexcavating the_Tower_of_Pis a_Back_to_Future (дата обращения: 20.03.2021).

7. Abelev M.Yu. Leveling the Tilts of a Tenement Building Founded on Loess Soils Prone to Slump-Type Settlement by Regular Wetting / M.Yu. Abelev, V.I. Krutov. - DOI https://doi.org/10.1023/A:1005260318917 // Soil Mechanics and Foundation Engineering. - 2000. - $\quad$ T 37, № 5. - C. 159-164. - URL: https://link.springer.com/article/10.1023\%2FA\%3A1005260318917 (дата обращения: 20.03.2021).

8. Pronozin Y.A. Geotechnical support for building construction in the changed basic design considerations of the superstructure / Y.A. Pronozin, N.Y. Kiselev, R.V. Melnikov, M.A. Stepanov // 16th Asian Regional Conference on Soil Mechanics and Geotechnical Engineering (16ARC), October 14-18, 2019 / Тайбэй: Chinese Taipei Geotechnical Society, 2020. - C. RGS-007. 
9. Fiorentino G. Numerical and experimental analysis of the leaning Tower of Pisa under earthquake / G. Fiorentino, D. Lavorato, G. Quaranta, A. Pagliaroli, G. Carlucci, C. Nuti [и др.]. — DOI https://doi.org/10.1016/j.proeng.2017.09.559 // Procedia Engineering. — 2017.

- $\begin{array}{lllll}\text { T } 199 . & \text { C. 3350-3355. U U }\end{array}$ https://www.sciencedirect.com/science/article/pii/S187770581734078X (дата обращения: 23.03.2021).

10. Pronozin Y.A. Structural safety of buildings in excess values of differential settlements / Y.A. Pronozin, L.R. Epifantseva, M.D. Kajgorodov. — DOI https://doi.org/10.1088/1757-

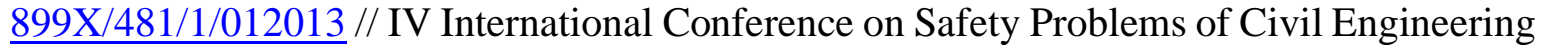
Critical Infrastructures 4-5 October 2018 / Екатеринбург: IOP Publishing Ltd, 2019. - C. 12013. — URL: https://iopscience.iop.org/article/10.1088/1757-899X/481/1/012013 (дата обращения: 23.03.2021).

11. Chen Yj. Analytical Plastic Solution Around Soil-Digging Holes for Inclined Building and its Application / Yj. Chen, X. Zhang. — DOI https://doi.org/10.1007/s40999-017-0230-7 // International Journal of Civil Engineering. — 2019. - T 17, № 2. - C. 245-252. — URL: https://link.springer.com/article/10.1007\%2Fs40999-017-0230-7 (дата обращения: 23.03.2021).

12. Ovando-Shelley E. Mexico City's Metropolitan Cathedral and Sagrario Church 13 Years After Underexcavation and Soil Hardening / E. Ovando-Shelley, E. Santoyo-Villa, J. Hernández. — DOI https://doi.org/10.1080/15583058.2015.1113331 // International Journal of Architectural Heritage. - 2016. - T 10, № 2-3. - C. 346-359. - URL: https://www.tandfonline.com/doi/full/10.1080/15583058.2015.1113331 (дата обращения: 23.03.2021).

13. Ibragimov M.N. Settlement stabilization of a reconstructed building / M.N. Ibragimov. DOI https://doi.org/10.1007/s11204-011-9115-y // Soil Mechanics and Foundation Engineering. - 2011. - T 47, № 6. - C. 236-240. - URL: https://link.springer.com/article/10.1007\%2Fs11204-011-9115-y (дата обращения: 23.03.2021).

14. Ovando-Shelley E. Underexcavation for Leveling Buildings in Mexico City: Case of the Metropolitan Cathedral and the Sagrario Church / E. Ovando-Shelley, E. Santoyo. - DOI https://doi.org/10.1061/(ASCE)1076-0431(2001)7:3(61) // Journal of Architectural Engineering. - 2001. - T 7, № 3. - C. 61-70. - URL: https://ascelibrary.org/doi/10.1061/\%28ASCE\%2910760431\%282001\%297\%3А3\%2861\%29 (дата обращения: 23.03.2021).

15. Mishra S.R. A Semi-Analytical Approach to Time Dependent Squeezing Flow of $\mathrm{Cu}$ and Ag Water-Based Nanofluids / S.R. Mishra, D.P. Bhatta, J.K. Dash, O.D. Makinde. - DOI https://doi.org/10.4028/www.scientific.net/DDF.393.121 // Defect and Diffusion Forum. 2019. - T 393. - C. 121-137. — URL: https://www.scientific.net/DDF.393.121 (дата обращения: 23.03.2021).

16. Ter-Martirosyan Z.G. The incompressible pile draft and bearing capacity when interacting with surrounding and underlying soils, taking into account their linear and elastic-plastic properties / Z.G. Ter-Martirosyan, G.O. Angelo, A.Z. Ter-Martirosyan. - DOI https://doi.org/10.1088/1757-899X/698/2/022041 // International Scientific Conference "Construction and Architecture: Theory and Practice of Innovative Development" 1-5 October 2019, Kislovodsk, Russian Federation / Кисловодск: IOP Publishing Ltd, 2019. C. 22041. - URL: https://iopscience.iop.org/article/10.1088/1757-899X/698/2/022041 (дата обращения: 23.03.2021). 
17. Barvashov V.A. Sensitivity of structures and geological data / V.A. Barvashov, G.G. Boldyrev. - DOI https://doi.org/10.7712/120117.5749.17068 // 6th ECCOMAS Thematic Conference on Computational Methods in Structural Dynamics and Earthquake Engineering, Rhodes Island, Greece, 15-17 June 2017 / Родос: National Technical University of Athens (NTUA), 2017. - C. 4634-4644. - URL: https://www.eccomasproceedia.org/conferences/thematic-conferences/compdyn-2017/5749 (дата обращения: 23.03.2021).

18. Ter-Martirosya A.Z. Numerical simulation of the structures bases stress-strain state taking into account the time factor / A.Z. Ter-Martirosyan, Z.G. Ter-Martirosyan, V.V. Sidorov. DOI https://doi.org/10.1088/1757-899X/456/1/012094 // VII International Symposium Actual Problems of Computational Simulation in Civil Engineering 1-8 July 2018, Novosibirsk, Russian Federation / Новосибирск: IOP Publishing Ltd, 2018. - C. 12094 - URL: https://iopscience.iop.org/article/10.1088/1757-899X/456/1/012094 (дата обращения: 28.03.2021).

19. Bartelletti R. Behavior of the Leaning Tower of Pisa: Analysis of Experimental Data from Structural Dynamic Monitoring / R. Bartelletti, G. Fiorentino, G. Lanzo, D. Lavorato, G.C. Marano, G. Monti [и др.]. — DOI https://doi.org/10.4028/www.scientific.net/AMM. 847.445 // Applied Mechanics and Materials. - 2016. - T 847. - C. 445-453. — URL: https://www.scientific.net/AMM.847.445 (дата обращения: 28.03.2021).

20. Li L. A Laboratory Study of Shear Behaviour of Rockbolts Under Dynamic Loading Based on the Drop Test Using a Double Shear System / L. Li, P.C. Hagan, S. Saydam, B. Hebblewhite, C. Zhang. - DOI https://doi.org/10.1007/s00603-019-01776-x // Rock Mechanics and Rock Engineering. - 2019. - T 52, № 9. - C. 3413-3429. - URL: https://link.springer.com/article/10.1007\%2Fs00603-019-01776-х (дата обращения: 28.03.2021).

21. Wang $\mathbf{X}$. The application research of comprehensive landing method during the rectification for the brick-concrete buildings in soft soil area / X. Wang, X. Zhang, S. Shi, L. Liu. - DOI https://doi.org/10.1260/1708-5284.12.4.375 // World Journal of Engineering. - 2015. $\begin{array}{lllll}\text { T 12, № } 4 . & \text { C. 375-382. } & - & \text { URL: }\end{array}$ https://www.emerald.com/insight/content/doi/10.1260/1708-5284.12.4.375/full/html (дата обращения: 28.03.2021).

22. Yune C.Y. Analysis of consolidation settlement of normally consolidated soil by layering under 3D conditions / C.Y. Yune, C.G. Olgun. - DOI https://doi.org/10.1007/s12205-0150171-0 // KSCE Journal of Civil Engineering volume. - 2016. - T 20, № 6. - C. 22802288. - URL: https://link.springer.com/article/10.1007\%2Fs12205-015-0171-0 (дата обращения: 28.03.2021).

23. Sert S. Numerical Investigation of Different Superstructure Loading Type Effects in Mat Foundations / S. Sert, A.N. K1lıç. — DOI https://doi.org/10.1007/s40999-016-0013-6 // International Journal of Civil Engineering. — 2016. - T 14, № 3. - C. 171-180. — URL: https://link.springer.com/article/10.1007\%2Fs40999-016-0013-6 (дата обращения: 28.03.2021).

Сведения об авторах:

Пронозин Яков Александрович - доктор технических наук, профессор, ФГБОУ ВО «Тюменский индустриальный университет», Тюмень, Россия, e-mail: pronozinja@gmail.com

ORCID: https://orcid.org/0000-0002-6173-2796

РИНЦ: https://elibrary.ru/author_profile.asp?id=415568

SCOPUS: https://www.scopus.com/authid/detail.url?authorId=55390829400 
Кайгородов Михаил Дмитриевич - ассистент, аспирант, ФГБОУ ВО «Тюменский индустриальный университет», Тюмень, Россия, e-mail: heklerkox@gmail.com

ORCID: https://orcid.org/0000-0002-4671-5541

РИНЦ: https://elibrary.ru/author_profile.asp?id=962374

SCOPUS: https://www.scopus.com/authid/detail.url?authorId=57208104250

Гербер Александр Давидович - кандидат физико-математических наук, профессор, ФГКВОУ ВО «Тюменское высшее военно-инженерное командное училище имени маршала инженерных войск А.И. Прошлякова» Министерства обороны Российской Федерации, Тюмень, Россия, e-mail: gerber_a@mail.ru ORCID: https://orcid.org/0000-0002-9611-5659

РИНЦ: https://elibrary.ru/author_profile.asp?id=296806

Статья получена: 25.05.2021. Принята к публикации: 23.07.2021. Опубликована онлайн: 06.08.2021. 